\title{
REVISITING HOBBES : ON FREEDOM, POLITICAL AUTHORITY AND CIVIL DISOBEDIENCE
}

\author{
[ REVISITANDo HobBes: SOBRE LIBERDADE, AUTORIDADE POLÍTICA E DESOBEDIÊNCIA CIVIL ]
}

\author{
Marta Nunes da Costa* \\ Universidade Federal do Mato Grosso do Sul, Brasil
}

\begin{abstract}
This paper has two main sections. First, I argue that Hobbes was capable of providing a convincing model of political authority that strengthened the absolutist monarchy, due to two main factors: on the one hand, Hobbes' conceptualization of freedom, which allowed him to offer a new light upon the relationship between obedience, obligation, freedom and servitude; on the other hand, Hobbes' redefinition of sovereignty via the concept of representation. I show how Hobbes was aware of the intrinsic tension derived from the attempted convergence of these two distinct logics and I question the kinds of political rupture that are possible under Hobbes' design, in such a way that would keep a democratic instinct and impulse in political life. After I revisit the relationship between freedom, power and civil disobedience, by looking at the relationship between the sovereign's and the subjects' capacity of judgment and by reflecting upon contemporary democratic challenges..
\end{abstract}

KEYwORDS: dominion; freedom; Hobbes; political authority; submission
RESUMO: Este artigo apresenta duas partes principais. Na primeira parte, argumento que Hobbes foi capaz de fornecer um modelo convincente de autoridade política que fortaleceu a monarquia absolutista, devido a dois fatores principais: por um lado, a conceituação da liberdade, que lhe permitiu oferecer uma nova luz sobre a relação entre obediência, obrigação, liberdade e servidão; por outro lado, a redefinição de soberania, por meio do conceito de representação. $\mathrm{Na}$ segunda parte, mostro como Hobbes estava ciente da tensão intrínseca derivada da tentativa de convergência dessas duas lógicas distintas e questiono os tipos de ruptura política que são possíveis sob o projeto de Hobbes, de tal modo que manteria um instinto democrático e um impulso político, depois de revisitar a relação entre liberdade, poder e desobediência civil, observando a relação entre a capacidade de julgamento do soberano e dos sujeitos e refletindo sobre os desafios democráticos contemporâneos.

Palavras-chaVe: domínio; liberdade; Hobbes; autoridade política; submissão

\section{REVISITING HoBBES}

$\mathrm{H}$ obbes was the first author to create, by transforming, a constellation of concepts that aimed at explaining, justifying and accounting for the specificities of the modern state. Although Bodin before Hobbes advanced a theory of sovereignty in The Six Books of the Republic (1576), in order to promote the peaceful endorsement of a new vision of the world where politics and religion came apart, his conceptualization of sovereignty was still very much entrenched with the belief that the

* Professora Adjunta do Curso de Filosofia da Universidade Federal do Mato Grosso do Sul. Professora Permanente do Programa de Pós-Graduação em Filosofia da Universidade do Oeste do Paraná-Unioeste.m@ilto: nunesdacosta77@gmail.com 
King, after all, had duties towards God. While the King was sovereign to do whatever he pleased, he was somehow constrained by the laws of nature and the divine laws that he would (hopefully) recognize. Although the concept of sovereignty accomplished this separation between the political and the religious sphere, which could be also seen as the 'invention' of the political as such, it was Hobbes who embedded this concept with a radically new impulse, unfolded in two other concepts: the concept of 'will' and the concept of 'representation'. The fact that Hobbes builds his argument appealing to two distinct logics reveals the oscillation between a democratic origin of politics and what could be interpreted as a authoritarian incarnation and/or expression of power. A democratic origin, insofar it is the consent of all that create the Civitas, the political community as such, or, in different words, 'the people'; an authoritarian expression of power because only by embracing a monarchical form of government is the art of politics capable of controlling the impulse of the (new) people becoming an ungovernable multitude. Despite this tension, I want to argue in this paper that Hobbes' political theory is radical, even in today's account, insofar what initially seems as a total alienation of one's power is in fact the exchange of power for freedom, a freedom that has a inalienable nature and that allows us to reconceive and image new possibilities for democratic life.

This paper has two main sections. In the first section, I argue that Hobbes was capable of providing a convincing model of political authority that strengthened the absolutist monarchy, due to two main factors: on the one hand, Hobbes' conceptualization of freedom, which allowed him to offer a new light upon the relationship between obedience, obligation, freedom and servitude; on the other hand, Hobbes' redefinition of sovereignty via the concept of representation. I show how Hobbes was aware of the intrinsic tension and problems derived from the attempted convergence of these two distinct logics and I question the kinds of political rupture that are possible under Hobbes' design. In the second section I revisit the relationship between freedom, power and civil disobedience from a twofold perspective. On the one hand, I look at the relationship between the sovereign's and the subjects' capacity of judgment; on the other hand, I reflect upon contemporary democratic challenges, more precisely, in what concerns the meanings and practices of 'the people'.

\section{HOBBES CONCEPTUALIZATION OF FREEDOM}

According to Skinner (2008) there are two conflicting theories of liberty: the republican theory that conceives freedom as non-domination and the Hobbesian theory that tries to refute the former. Quid sit libertas, Quid sit servitus? asks Bracton, a contemporary of Hobbes that he seems to be acquainted with. Bracton says that servitude is the institution of laws, against nature, through which someone is made a subject of another. (Skinner, 2008, pp.xi-xii) This means that laws have the power to transform human freedom in some kind of domination: submission, servitude or slavery. To loose one's freedom, according to this reading, is to become a subject of another, understood as arbitrary power. This was indeed the dominant understanding of freedom in political theory at the time of the civil war of 1642. The King was under attack by the Parliament defenders because he represented (so they argued) the arbitrariness of decision-making and the use of power that enslaved the population. Hobbes is the principal thinker against the republicans' theory of freedom.

There is not 'one' conceptualization of freedom in Hobbes; in fact, there are different formulations in The Elements of Law, De Cive and Leviathan. In De Cive, Hobbes affirms that freedom is nothing more than the 'absence of impediments'. Impediments can be external or absolute, on the one hand (if they are external, that means that physical objects, for instance, represent a real obstacle for the movement of the bodies) or they can be arbitrary, i.e., impediments that stop our movement by 
accident, not by our own choice.

In Leviathan, Hobbes enriches his previous conceptualization and transforms it in order to offer a more viable and persuasive alternative to republican's conceptualization of freedom. His theory of freedom is built upon a general theory of philosophy and of movement. In chapter IX Hobbes shows how philosophy, which is the 'science, i.e., knowledge of consequences' unfolds in different studies: the studies of accidents of natural bodies (natural philosophy) and the consequences from accidents common to all natural bodies (prima philosophia, where we find mathematics, geometry, arithmetic on the one hand, and cosmography, astronomy, geography, mechanics, engineering, architecture and navigation, on the other). Physics, or 'consequences from qualities' unfolds in the consequences from qualities of transient bodies (meteorology), of permanent bodies and of terrestrial bodies. It is under the scope of terrestrial bodies that we find consequences from parts of the earth without sense, but also with sense - such as ethics, speech or logic. Another distinctive branch is the study of consequences from accidents of political bodies, i.e., Politics or Civil Philosophy. Here we can study two things: the rights and duties of the sovereign and the right and duties of the subjects. (Hobbes, 1998, pp. 52-53) The book Leviathan is concerned with this last section of study. It is important to have this general structure of science in mind insofar it is this specific approach of politics via movement that makes Hobbes' proposal unique and radical. The uniqueness of Hobbes' proposal lies in the fact that against the scholastic or Aristotelian tradition that postulated some 'soul' or 'will' as faculty of the mind that would, in its turn, grant the conditions of existence for a moral domain, Hobbes reduces morality to a matter of human nature identified in the behaviors of bodies - individual and collective. In order to understand Hobbes' concept of freedom it is essential to grasp how this concept is intimately linked to the concepts of power and passion. In chapter XI Hobbes says

... the voluntary actions and inclinations of all men tend not only to the procuring, but also to the assuring of a contented life, and differ only in the way, which ariseth partly from the diversity of passions in diverse men, and partly from the difference of the knowledge or opinion each one has of the causes which produce the effect desired.

So that in the first place, I put for a general inclination of all mankind a perpetual and restless desire of power after power, that ceaseth only in death. And the cause of this is not always that a man hopes for a more intensive delight that he has already attained to, or that he cannot be content with a moderate power, but because he cannot assure the power and means to live well, which he hath present, without the acquisition of more. (Hobbes, 1998, p.61, my italics)

Men are moved by passions, actions are always the antecedents of passions that can either be appetites or fears. This means that if passion is what triggers and embodies actions, then, Hobbes is refuting the Aristotelian thesis that actions, and free actions in particular, can be moved by reason. In different words, Hobbes is radically inverting the dominant reading at the time about the relationship between passion and reason. Passions are not specific of animals, nor should they be dominated by men through reason; passions are essential, natural, implicit in every human action and there is no way of rejecting this or sublimating, as the humanists inspired by Plato or Aristotle tried to do. If passions are what constitute us, as humans, we must refuse the rationalist discourse that supports the direct association between passion and servitude. For Hobbes, passions are linked to freedom. How?

Previously, in chapter VI of Leviathan Hobbes says

In deliberation, the last appetite, or aversion, immediately adhering to the action, or to the omission thereof, is that we call the will; the act, not the faculty, of 
willing. And beasts that have deliberation must necessarily also have will. The definition of the will, given commonly by the Schools, that it is a rational appetite, is no good. For a voluntary act is that which proceedeth from the will, and no other. [...] Will, therefore, is the last appetite in deliberating. [...] the action depends $[\ldots]$ of the last inclination or appetite.' (Hobbes, 1998, p.38, my italics)

Three things to notice in this passage: first, Hobbes provides us with a definition of 'will'. Will is the act of willing. Second, Hobbes attacks the scholastic reading which reflected the Aristotelian thesis that there is a 'rational will' understood as faculty of the soul. For Hobbes this is non-sense. The will is only the act, nothing before or after. Third, the will is 'the last appetite in deliberating', i.e., it is the act, which is a result of a process of deliberation that ends as soon as it is accomplished. When are we actually free? When we deliberate, when we live the process arriving at a final decision translated in an action. The will, i.e., the act itself ends our freedom. As Skinner shows, there is ambivalence in Hobbes understanding of deliberation: between deliberare, understood as loss of freedom and librare, i.e, to weight in the balance. Libertas naturalis, i.e, the freedom in the state of nature is the freedom that emerges from necessity, it is the need of searching one's own ends. This is why Hobbes thinks of freedom as natural right. The concept of freedom is intimately linked with that of power.

In chapter $\mathrm{X}$ of Leviathan Hobbes says 'The power of a man, to take it universally, is his present means to obtain some future apparent good, and is either original or instrumental.' (Hobbes, 1998, p. 53) But the author continues,

The greatest of human powers is that which is compounded of the powers of most men, united by consent, in one person, natural of civil, that has the use of all their powers depending on his will; such as is the power of a Commonwealth: or depending on the wills of each particular, such as is the power of a faction, or of diverse factions leagued. Therefore, to have servants is power; to have friends is power: for they are strengths united. (idem)

The greatest power is that which combines, articulates and transforms the power of many (individuals) into one single agent or will. This applies both to natural persons or civil persons. Once different wills are reunited and act in a symbiotic and organized manner, they become something else: one will with more power, i.e., with more conditions to achieve goods. What is good? Good, obviously, is not defined via a morals lens, since Hobbes treats the will as an act, specific, individual, present, and not as a capacity of projecting actions in the future. Good is defined as that which contributes to one's survival, preservation and comfort. This will be crucial to understand the importance of the social pact.

\section{NATURAL RIGHTS TRANSFORMEd? From the STATE OF NATURE TO THE CREATION OF A CIVIL POWER}

Chapters XIII and XIV of Leviathan provide the scenario that aims at convincing us of the necessity of the social pact. On chapter XIII, 'Of the natural condition of mankind as concerning their felicity and misery', Hobbes argues that 'nature hath made men so equal in the faculties of body and mind [...] for as to the strength of the body, the weakest has strength enough to kill the strongest, either by secret machination or by confederacy with others that are in the same danger with himself.' (Hobbes, 1998, p.76) The equality of starting-point transforms itself in the equality of hope in attaining one's own ends, which may collide with another's. This creates an atmosphere of fear and suspicion among men, a state of war, and a structural difficulty in living with others for "men have no please [...] in keeping company where 
there is no power able to overawe them all.' (Hobbes, 1998, p.77) From this it follows that nothing can be unjust, for 'where there is no common power, there is no law; where no law, no injustice.' (Hobbes, 1998, p.79)

On chapter XIV, Hobbes starts with the definition of freedom, understood as 'absence of external impediments', followed by the definition of lex naturalis, which is 'a precept, or general rule, found out by reason, by which a man is forbidden to do that which is destructive of his life, or taketh way the means of preserving the same, and to omit that by which he thinketh it may be best preserved.' (Hobbes, 1999, p.80) The first law of nature is to seek peace and follow it, the second, 'the sum of the right of nature' is 'by all means we can to defend ourselves'. (idem) Since there is no peace without submission that means that men must be willing to retain the necessary freedom as long as it is compatible with others', i.e., men must be willing to renounce their right, as long as all others do the same. The renouncing of right is not the same as the alienation of freedom; instead, it is only the 'diminution of impediments to the use of his own right original.' (Hobbes, 1998, p.81) How does one put aside one's original right? By renouncing or by transferring it, says Hobbes. In both cases, the abdication of one's original right brings with itself the birth of a new set of concepts and its correlative practices, namely, the concepts of obligation, duty, obedience and justice. Hobbes says

Whensoever a man transferreth his right, or renounceth it, it is either in consideration of some right reciprocally transferred to himself, or for some other food he hopeth for thereby. For it is a voluntary act: and of the voluntary acts of every man, the object is some good to himself. And therefore there be some rights which no man can be understood by any words, or other signs, to have abandoned or transferred. (Hobbes, 1998, pp.81-82)

Hobbes is saying that in both cases - of abandonment or transference of rights it is a matter of voluntary actions, which aim at a 'good'. However, he concludes by saying that not all rights can be transferred - some rights are inalienable. Which are those? He continues

As first a man cannot lay down the right of resisting them that assault him by force to take away his life, because he cannot be understood to aim thereby at any good to himself. The same may be said of wounds, and chains and imprisonment, both because there is no benefit consequent to such patience, as there is to the patience of suffering another to be wounded or imprisoned, as also because a man cannot tell when he seeth men proceed against him by violence whether they intend his death or not. And lastly the motive and end for which this renouncing and transferring of right is introduced is nothing else but the security of a man's person, in his life, and in the means of so preserving life as not to be weary of it. (Hobbes, 1998, p.82, my italics)

Notice that in the process of developing the argument for the necessity of the social contract, Hobbes emphasizes how certain rights cannot be alienated nor transferred. Man keeps the natural right of resistance to everything that threatens his life directly, or the means to preserve his life. The only reason for accepting to renounce or transfer one's right is to assure one's security; this is indeed the principal reason for the social pact or contract, i.e., the 'mutual transferring of right'. (idem) So there is a kind of ambivalence in Hobbes' conceptualization of social pact's necessity: it is necessary because without it men will not find the necessary nor the sufficient conditions to live in peace and to protect their own lives; however, despite the appearance of this 'mutual transferring of right' being total and absolute, each individual retains a ultimate right of self-preservation that cannot be ignored, but which remains, as long as the pact endures, 'suspended'.

The pact is necessary because it is not simply made of words, but of swords. As 
Hobbes says, '... the bonds of words are too weak to bridle men's ambition, avarice, anger and other passions, without the fear of some coercive power...' (Hobbes, 1998, p. 84) So, the pact has a specific character: one the one hand, in brings all individual and disperse wills together, creating 'One' will and One person; but this Person exists only insofar it has the power to keep its own existence, and here we are talking about a coercive power. Given that men are moved by passions, unless there is a common power capable of applying punishment for natural laws' violation, men would be condemned to live in a perpetual state of war against each other. The birth of a civil state eradicates the natural fear of violent death and it assures a comfortable existence for all. The Civitas represents a physical transformation of how the bodies are organized and, on the other hand, a symbolic transformation where security is desired above all and in name of that security each individual accepts to transform him/herself in a subject of an-Other. The covenant in Hobbes is more than a mere pact. It is the act by which every single individual is permanently transformed and by which the project of human nature can be redirected according to the ideal of a well-ordered society.

The ideal of a well-ordered society does entail a social pact, as described by Hobbes, but not all covenants are possible. There are some covenants logically impossible to do:

A covenant not to defend myself from force, by force, is always void. For ... no man can transfer or lay down his right to save himself from death, wounds, and imprisonment, the avoiding whereof is the only end of laying down any right; and therefore the promise of not resisting force, in no covenant transferreth any right, nor is obliging. (Hobbes, 1998, p. 86)

Hobbes is reiterating that autonomous dimension in every single individual that remains solid and integral. So, if someone tries to kill me I naturally chose to resist. There is no covenant that could force me to lay down the right of self-defense; any such attempt would be void, just like a covenant to accuse oneself, which is also invalid. (idem).

What does a covenant? It creates civil power; it brings it to existence, along with justice, i.e., the means to keep valid covenants. The covenant requires externalization, words, promises, which have a direct impact as a reconfiguration of bodies' movements; it requires the invention of new laws, civil laws, capable of doing what the laws of nature seem insufficient to accomplish, given that they oblige only in foro interno. (Hobbes, 1998, p.97) It also requires the invention of a new actor, a new body, a new person, capable of embodying initially dispersed individuals into 'One' articulated and sound voice and will.

\section{REFLECTIONS ON THE CIVIL STATE: FREEDOM, SUBMISSION AND SUBJECTION OR 'THE PRODUCTION OF SUBJECTIVITIES'}

While laws of nature 'oblige' to a certain point, this is a special type of obligation, an obligation that does not entail (legal) law or justice. We could say that it is a 'symbolic' obligation, for it lives in foro interno, it does not find the external criteria that would define it as obligation for oneself and for others. In different words, laws of nature exist only for/in the individual, it is a mater of conscience, but there is no external horizon of recognition and reciprocity between subjects simply because there are no subjects in that preliminary state of nature. Only individuals governed by their own passions: fears and appetites ${ }^{1}$.

Justice requires the invention of a sphere of external communality, i.e., it implies the abandonment of each self as individual and the transformation of the individual into a subject that is a subject because $\mathrm{s} / \mathrm{he}$ is subjected to laws; and to say that $\mathrm{s} / \mathrm{he}$ is subjected to laws - external laws - implies that there is a common, objective, external 
power capable of assuring its conditions of existence: a power that is not subject(ed) to an-Other, instead, it is a power that is Sovereign. Under this light, justice as such only arises when men gather and agree to create this common power capable of placing them 'in order'. And how is order maintained, or what does it imply?

The primary motive to create a commonwealth is the fear of (violent) death. In order to escape or to overcome this fear, individuals voluntarily accept and consent to transfer their (natural) rights to a common power, which does not exist prior to this movement of mutual transference. This transference unfolds in different aspects, dimensions and concepts: first, the transference, which is voluntary, i.e., an act, a will, represents the end of a process od deliberation, which means, it brings with itself the end of freedom as we know it in the state of nature. Indeed, the transference implies the abandonment of the right to all things; the Person created via all mutual transferences will be the Will authorized to manage these previous rights. Second, the end of freedom as we know it in the state of nature does not mean the end of freedom tout court. On the contrary, Hobbes is keen in arguing that there is no incompatibility between the constitution of political authority and freedom. This transference transforms 'freedom', not in its core meaning (absence of impediments), but in its sphere of application or exercise. The creation of a Sovereign entails the transformation of individuals into subjects. As subjects, subjected to a higher power, all are obliged to obey. Freedom is born out of the act of submission, which brings the recognition of one's obligation. The state of nature ends once submission - not freedom - enters the picture. Again, this submission should not be interpreted as rejection of one's freedom but its opposite; submission is a proof of one's freedom also expressed in the invention of subjectivity, i.e., while submission happens once and for all, representing the end of a cycle, it creates subjects that must remain subjects via a constant process of subjection and 'subjectivation' vis-à-vis the Commonwealth ${ }^{2}$. Third, this transference, which coincides with the constitution of Sovereignty, allows the creation of a different sphere - a public sphere - with public criteria that distinguishes good and desirable deeds from bad and undesirable behaviors. In different words, the public sphere is the sphere where the dispersed multitude dies giving place to individual subjects now tied by external common laws and precepts that can finally establish a criterion of justice and punishment. The public sphere allows the appearance of each individual as subject capable of recognizing oneself and others as such. The process of recognition is literally enlightened by the Sovereign.

\section{HobBes CONCEPTUALIZATION OF SOVEREIGNTY}

It is on Chapter XVI of Leviathan that Hobbes puts in evidence the sharp and necessary distinction between the natural and the artificial worlds. The natural world is made of bodies in movement, governed by natural laws, however, it is a world deprived of human laws and of justice. The artificial world, on the contrary, is a world made by humans, and is of humans' total responsibility. The artificial world comes to existence with the mutual transference of rights between single individuals; this contract creates an artificial person where Sovereignty stands for a 'artificial soul' and where magistrates are artificial joins and laws are artificial reason. Why 'artificial person'? Hobbes says

A person is he whose words or actions are considered, either as his own, or as representing the words or actions of another man, or of any other thing to whom they are attributed, whether truly or by fiction.

When they are considered as his own, then is he called a natural person: and when they are considered as representing the words and actions of another, then is he a 
feigned or artificial person. (Hobbes, 1998, p.98)

He continues

Of persons artificial, some have their words and actions owned by those whom they represent. And then the person is the actor, and he that owneth his words and actions is the author, in which case the actor acteth by authority. [...] So that by authority is always understood a right of doing any act; and done by authority, done by commission or license from him whose right it is. (Hobbes, 1998, p.99)

The covenant creates an actor who is entitled to act and represent the author, but 'the covenant obligeth the author only, not the actor [...]' (Hobbes, 1998, p.100) Who is represented? Is it the individuals, singularly considered? How do we go from individual wills to an actor capable of representing all those involved in the covenant? Hobbes says

A multitude of men are made one person when they are by one man, or one person, represented; so that it be done with the consent of every one of that multitude in particular. For it is the unity of the representer, not the unity of the represented, that maketh the person one. And it is the representer that beareth the person, and but one person: and unity cannot otherwise be understood in multitude. (Hobbes, 1998, p.101)

Individual wills constitute a multitude, which by definition is many; by converging in the covenant they transform themselves into One, a 'One' that can be represented, that can act in their name, that can create a Artificial body more perfect than the dispersion of natural ones. This convergence signifies the act of consent, which is an act of submission to some-One who does not exist prior to the covenant. It is submission that creates the artificial will. It is submission, as act of individual wills, as act of freedom that creates the Artificial Person. Each individual act makes the Other his/her sovereign.

Chapter XVII of Leviathan is the first chapter concerned with the post-covenant life. It starts by strengthening the idea that it is necessary to restrain men's liberty in order to guarantee their own preservation and 'a more contented life' (Hobbes, 1998, p. 103). But the covenant alone is incapable of creating this brave new world where subjects can finally live with safety; for 'covenants, without the sword, are but words and of no strength to secure a man at all.' (idem) Covenants are only relevant and utile if and only if they are secured by a background 'terror of some power' capable of imposing the observance of natural laws, now transfigured into legal laws. Peace is only possible if a common power is erected capable of maintaining all in awe. There is only peace with subjection; there is only freedom with dominion. How is such a common power erected then? Hobbes answers

[by conferring] all their power and strength upon one man, or upon one assembly of men, that may reduce all their wills, by plurality of voices, unto one will: which is as much as to say, to appoint one man, or assembly of men, to bear their person; and every one to own and acknowledge himself to be author of whatsoever he that so beareth their person shall act, or cause to be acted, in those things which concern the common peace and safety; and therein to submit their wills, every one to his will, and their judgments to his judgment. This is more than consent, or concord; it is a real unity of them all in one and the same person, made by covenant of every man with every man, in such manner as if every man should say to every man: I authorize and give up my right of governing myself to this man, or to this assembly of men, on this condition; that thou give up, thy right to him, and authorize all his actions in like manner. This done, the multitude so united in one person is called a Commonwealth; in Latin, Civitas. This is the generation of the great Leviathan, or rather, to speak more reverently, of that 
mortal god to which we owe, under the immortal God, our peace and defence. [...] And in him consisteth the essence of the Commonwealth; which, to define it, is: one person, of whose acts a great multitude, by mutual covenants one with another, have made themselves everyone the author, to the end he may use the strength and means of them all as he shall think expedient for their peace and common defence. (Hobbes, 1998, p.106, my italics)

Notice how Hobbes introduces the concept of sovereignty via an articulation of concepts of power, will, actor and author(ization). The sovereign is that who transforms the multitude into One actor; the sovereign is that where the power and strength of all subjects are concentrated; the sovereign transforms individuals into subjects, and in doing so, creates the duty to obedience, it creates obligations. The sovereign is the mortal god because it is the artificial person constituted by all. The sovereign is a product of individual wills and stands for a new powerful will, a will that 'beareth their person'. The sovereign is the mirror where each individual sees her/himself, it is 'a real unity of them all'. Once the sovereign comes to existence, there is no longer 'individuals' as conceived in the previous state of nature; their nature is transformed, they are now totally identified with the sovereign, their unity is symbiotic, existential and symbolic. We arrive at the identity between sovereign, commonwealth and subjects. They are one and the same.

To say that sovereignty, commonwealth and subjects are one and the same has extreme political implications from a contemporary point of view. First, it means that submission of all creates sovereignty, on the one hand, and freedom, on the other. Sovereignty is the artificial person that brings to existence the conceptual, symbolic and physical networks that are necessary and sufficient to assure a well-ordered society. The conceptual network unfolds in the categories of author, actor and representer, as 'subjects' of sentences and of actions and, on the other hand, authorization, actorship and representation as new forms of social and political relationships that directly contribute to a) the process of formation of new subjectivities and b) the process of formation of justice and collective values. The sovereign is the actor who is fully authorized to act as he pleases and judges to be the best. Since all subjects authorized the sovereign in becoming what he is now, the sovereign is their representer. There is no such thing as bad representation or misrepresentation of subjects, as we will further see. The sovereign also creates a cultural, political and juridical horizon where morality emerges. Morality however should be considered from a materialistic point of view, i.e., actions are 'good' or 'bad', i.e., they are permitted or non-permitted according to the effects they have on the larger goal: social and political stability. The sovereign, because he is the representer, is also the only and final judge in matters of dilemmas. Through civil laws, the sovereign defines the boundaries for freedom. Again, freedom is not a metaphysical category, but a physical one; it is a matter of movement of bodies, individual and collective ones ${ }^{3}$.

Second, sovereignty is created via submission, but it creates two apparently conflicting realities, namely, subjection and freedom. This conflict is only apparent: there is only freedom where there is law - civil laws set the necessary conditions for freedom's exercise; at the same time, subjection means to be subject to an-Other, in this case, all individuals become subject of the sovereign. On the other hand, subjection also means the process of becoming a subject, of transforming one's own subjectivity. How does this transformation happen? Enlightened by the sovereign's public judgment on what constitutes a 'good subject', i.e., a subject that contributes to the maintenance of the social order and not the opposite. In different words, collective subjection sets the conditions of possibility for individual freedom as process of constitution of one's subjectivity according to direct or indirect orientations of the Sovereign.

Third, the subject, who always authorizes the sovereign, finds in the sovereign her/his condition of existence. This should be understood literally: from an external 
point of view, the sovereign is the ontological foundation of every subject, insofar he is the one who has the monopoly of force and who, in a state of nature against other individual sovereigns (or nations) can do everything to protect itself; in doing so, he is protecting his subjects. From an internal point of view, the sovereign also protects individual subjects from their peers if these peers represent an eminent threat to the social order. Hobbes tells us that

As men, for attaining of peace and conservation of themselves thereby, have made an artificial man, which we call a Commonwealth; so also have they made artificial chains, called civil laws, which they themselves, by mutual covenants, have fastened at one end to the lips of that man, or assembly, to whom they have given the sovereign power, and at the other to their own ears. These bonds, in their own nature but weak, may nevertheless be made to hold, by the danger, though not by the difficulty of breaking them. (Hobbes, 1998, p. 130)

Freedom is born out of individuals' submission and construction of a Sovereign; its other side is obligation: individuals, transformed into subjects, are obliged to obey. If freedom under such scenario requires laws to acquire ontological significance, it does not make sense to conceive the possibility of freedom as "exemption from laws'4. Indeed,

The liberty of a subject lieth therefore only in those things which, in regulating their actions, the sovereign hath pretermitted: such as is the liberty to buy, and sell, and otherwise contract with one another; to choose their own abode, their own diet, their own trade of life, and institute their children as they themselves think fit; and the like. (Hobbes, 1998, p.131)

From these three aspects arises the inevitable question: if subjects are to a certain extent hostages of the Sovereign's will, action and judgment, is there room to conceive civil disobedience in Hobbes? What happens to individual wills? Are subjects deprived of their will? Conceptual and practically speaking they cannot, because will is action, and subjects are free - they act according to their own process of deliberation, they pursue their interests, they search for the fulfillment of their own conception of 'good life' as long as it does not violate civil laws. As I have suggested, Hobbes is not simply concerned with subject as such; his goal is to delineate or sketch how subjects become good subjects. Good subjects are those who construct their own subjectivity under the light and precepts of legal laws and public judgment about what is good and what is evil. A good subject is a subject who contributes to the stability of the commonwealth, who adjusts one's desires to the horizon of permissibility of acts, remaining free where the laws are silent. A good subject is a subject that is permanently subjected and redefines one's own subjectivity according to the Sovereign's will and judgment. So, how is it possible for any subject to question the sovereign's authority? It seems that good subjects would not be capable, in principle, of disobeying the Sovereign. Is Hobbes offering a guide on how to delegitimize all forms of disobedience or rebellion? Does the primary and ultimate act of submission that produces subjectivities erode the conditions of possibility for its contestation? Is Hobbes arguing that the Sovereign is always right? Again, we must be cautious not to extrapolate or to get caught in a realm of pure abstraction when thinking of a possible situation of disobedience. Ultimately, it does not make sense to attribute 'right' to the sovereign (as moral connotation) for the Sovereign is the one who creates the criteria of right and wrong, i.e., Hobbes is building a immanent conceptualization of morals; he is not oscillating between a meta-level, nor his he appealing to meta-criteria that would permit a final judgment on practical moral criteria in the world.

While Hobbes is certainly concerned with defining the sufficient means to assure a well-ordered society, he does not abdicate from the natural right of resistance or disobedience. We saw previously how Hobbes protected this right and defined it as 
inalienable under specific circumstances. The problem then is to define which circumstances would allow for civil disobedience or rebellion in Hobbes. This is the topic of our next section.

\section{FREEDOM AS POWER - CIVIL DISOBEDIENCE RECONSIDERED}

\section{SOVEREIGNTY AND JUDGMENT}

\section{On chapter XVIII of Leviathan Hobbes says that every man}

[shall] authorize all the actions and judgments of that man, or assembly of men, in the same manner as if they were his own, to the end to live peaceably amongst themselves and be protected against other men. (Hobbes, 1998, p.107)

The act of constitution of Sovereignty is the act through which individuals 'submit their wills, every one to his will, and their judgments to his judgment.' (Hobbes, 1998, p. 106) If judgments in the state of nature were essentially private and with no means to be enforced, in the commonwealth judgments acquire a public character and point to a larger structure of coercive power and law enforcement. One could ultimately say that judgments in the state of nature are condemned to silence and invisibility, while in the commonwealth they find conditions for their existence. The political and artificial body allows therefore: a) to make judgments public; b) to find recognition for it; c) to resolve disputes and conflicts. Under this light, one of the main tasks of the Sovereign is to create criteria for judgments' evaluation and laws' enforcement. This criterion is the sovereign himself, i.e., as Lloyd puts it

If we understand the sovereign to be the authoritative arbitrer of all disputes, it follows that she may legitimately settle disputes as to what the law - including natural law - is, how it is properly interpreted, whether a particular question falls under any existing law, whether she has or has not rightly judged the question at hand, whether she has or has not exceeded its legitimate authority, and the like. Absolutism falls out of this grant of authority to judge all disputes. (Lloyd, 2009, p.280, original italics)

For Lloyd, this is the crucial point, namely, that the sovereign collides natural law with civil law, making impossible to conceive alternative meanings of natural law by itself. In different words, if the Sovereign becomes the actor who defines the criteria of judgment, evaluation and punishment, then it becomes impossible to conceive a) the meanings and content of natural laws and b) the distinction between natural and civil law; c) the conditions under which it would be possible to suspend civil law and recover natural law. Under this light,

There is no sense to be given to the idea that we should disobey the sovereign's declarations of positive law on the ground that in our judgment they conflict with the natural law. Natural law commits us to regarding the judgment of the sovereign as authoritatively and properly adjudicating all disputes, including those over what does or does not conflict with natural law [...] It would thus seem that Hobbes's position contains a strongly positivistic element. Natural law has supreme authority; but it directs us, first and foremost, to act as if legal positivism were true. Natural law is thus self-effacing. (Lloyd, 2009, p.280 original italics)

It would seem that Hobbes is simultaneously a defender of natural law and a legal positivist insofar there is no way how to judge the actual correspondence between civil and natural laws. Ultimately, the Sovereign is always right and his actions always 
authorized by all subjects. Obedience of subjects is, in a twisted way, a form of recognition of the necessary horizon of freedom. Does this mean that all acts of obedience are just and that there is no space for justifying rebellion or disobedience? Byron says

The problem seems to be that if subjects are responsible for their own unjust obedience, then their motivation to obey the civil law will be sapped. The very subjection that constitutes a unified agent in the artificial person of the sovereign precludes this possibility: this problem cannot arise for good subjects. Good subjects are obligated to obey the law, whatever it is. (Byron, 2015, p.113)

Hobbes tells in Leviathan that the Sovereign is the ultimate judge in deciding controversies, civil or natural law, or fact. (Hobbes, 1998, p.110) The sovereign is also responsible for deciding which matters of opinion or doctrines are acceptable, and which are non-permissible. We have seen that the relationship between sovereign and subjects is symbiotic, i.e., a multitude of men transfigures itself in One person, with One collective, artificial body. This relationship is one of mutual interdependence, however, for it to fulfill its purpose (granting peace and stability) it must be asymmetrical. The sovereign has all rights (or almost), while the subjects have the duty to become good subjects, i.e., vital elements that contribute to the peace they want to secure. Obedience is the necessary condition to become a good subject. According to Byron, good subjects are always obliged to obey the law, regardless of the content of the law; it is not only a matter of being compelled to comply with the law because the sovereign has the coercive power and physical force to oblige it; it is a matter of radically transforming individuals in obedient subjects. However, while obedience is a necessary prerequisite for peace and the counter-part of sovereign's authority, it admits of exceptions, i.e., Hobbes grants space for disobedience, even if under specific and exceptional circumstances.

\section{SUBJECTS AND JUDGMENT}

What are these exceptional circumstances? Previously in chapter XIV Hobbes told us that all covenants, which do not defend a man's body are void. Here he makes explicit the circumstances under which is legitimate to refuse or disobey, as an act of freedom.

First, man has the right to refuse a command that orders one's death. He says

No man is bound by the words themselves, either to kill himself or any other man; and consequently, that the obligation a man may sometimes have, upon the command of the sovereign, to execute any dangerous or dishonourable office, dependeth not on the words of our submission, but on the intention; which is to be understood by the end thereof. When therefore our refusal to obey frustrates the end for which the sovereignty was ordained, then there is no liberty to refuse; otherwise, there is. (Hobbes, 1998, p.134)

Second, man has the right to protect himself will all the means available under a scenario where the sovereign is no longer capable of acting as such:

The obligation of subjects to the sovereign is understood to last as long, and no longer, than the power lastheth by which he is able to protect them. For the right men have by nature to protect themselves, when none else can protect them, can by no covenant be relinquished. The sovereignty is the soul of the Commonwealth; which, once departed from the body, the members do no more receive their motion from it. The end of obedience is protection; which wheresoever a man seeth it, either in his own or in another's sword, nature 
applieth his obedience to it, and his endeavor to maintain it. And though sovereignty, in the intention of them that make it, be immortal; yet is it in its own nature, not only subject to violent death by foreign war, but also through the ignorance and passions of men it hath in it, from the very institution, many seeds of a natural mortality, by intestine discord. (Hobbes, 1998, p.136)

Obedience is always necessary for peace, as it is subjection. The dangers an individual faces as member of the commonwealth are not only external, i.e., other commonwealths that are public enemies and try to conquer, for instance. The dangers are also internal, they are intrinsic to the social body, for their translate human nature, i.e., man's ignorance and passion which constitute an 'intestine discord'. For this reason, the Sovereign has the double task of assuring peace vis-à-vis other states, and peace within, among subjects. When the sovereign is no longer capable of assuring peace, then, subjects are no longer obliged to obey.

In radical or extreme situations, one sees how subjects recover their primal right of self-preservation: in contexts of war, of institutional disruption when institutions are no longer properly functioning nor can they assure the respect for civil laws and punishments, or similar scenarios. But what about situations that are not extreme but which, one could argue, fail to assure stability and peace? Where would we place the threshold of tolerance to sovereign's incapacity to fulfill his only duty? Here, the answer is not as black and white as in the case of extreme scenarios, specially because it exposes the intrinsic tension in Hobbes project: if individuals are left to themselves to judge which of Sovereign's actions are morally good or right, then they may be prisoners of their own bias and self-interests. In different words, if individuals believe to have the right to judge the Sovereign, it is probable that subjects evaluate sovereign's actions in terms of how they seem fit to their own interests. Hobbes solves this difficulty by converging the subjects' interests with the Sovereign's judgment and action. That is why only the Sovereign is apt to give a moral interpretation of facts; otherwise, if we 'democratize' the condition of moral judgment we are ultimately inviting the proliferation of civil disobedience and conflict ${ }^{5}$. But then, how could one rescue the possibility for individual judgment? Is it possible to do so?

The first thing to have in mind is that Hobbes is indeed mistrustful of the multitude - that dispersion of individuals which exist and characterize the state of nature, and which represent the potentially worse of human nature. The multitude stops existing once 'the people' is created; 'the people' is created by and in the name of the sovereign. The people and the sovereign are parts of the same coin. Therefore, if 'the people' consists of a unity of different individual members tied by One will, to raise the question of possibility for civil disobedience would, in a first glance, be non-sense, because to assume that civil disobedience is possible is already to treat the political body as disfigured and destroyed. If individuals are no longer tied by duties of obedience and subjection, then, by itself, it is a sign that individuals are no longer subjects but singulars; as singulars they are thrown again in the state of nature where the right to all things becomes the maxim of action. This also means that it is a false question to search for a criterion of legitimacy for individual and collective judgments that may entail civil disobedience. If the Sovereign is no longer capable of assuring public and general criteria of right and wrong, of morals and political life, then everything is allowed and there is no need (nor does it make sense) to introduce the question of legitimacy.

What if the multitude agrees on an act of civil disobedience or even rebellion? What if several individuals give their consent to such an act? Hobbes says in the beginning of Book II of De Cive, that

... divided in their opinions they will be an hinderance to each other, of if they agree well enough to some one action through hope of victory, spoyle, or revenge, yet afterward through diversity of wits, and Counsels, or emulation, and envy, 
with which men naturally contend, they will be so torne and rent, as they will neither give mutual help, nor desire peace, except they be constrained by it by some common feare. Whence it followes that the consent of many [...] yeelds not that security which they seek for [...] but that somewhat else must be done, that those who have once consented for the common good, to peace and mutuall help, may by fear be restrained, lest afterward they again dissent, when their private Interest shall appear discrepant from the common good. (HOBBES, 1984, p.87)

A Commonwealth requires not only consent but also union, as it formulated in De Cive. In Leviathan this means that the Commonwealth means the construction of One body, One will, One action, i.e., One Sovereign. Union is accomplished via submission. To question the act of submission is already a proof of disunion. Unless there is the common fear to keep us in order, there is no civil Person, no Power and ultimately, no Freedom. This is why subjects must always surrender their ability to question the sovereign's legitimacy, 'for the sovereign's commands are not merely incentives for the efficient satisfaction of the subject's aims or goals, but authoritative directives which, as such, introduce genuine reasons rather than arbitrary considerations.' (Venezia, 2015, p.56)

\section{CONCLUDing REMARKS}

At this point it seems pertinent to raise the question: how does Hobbes' theory of political obligation help us enlightening, understanding and addressing contemporary democratic challenges, more precisely, how can Hobbes help us to attribute a meaning to the intrinsic conflict of democratic life between 'the people' versus 'the multitude'? Is Hobbes a pertinent author to conceive the possibility for civil disobedience today?

As Jakonen argues (2016) Hobbes has a paradoxical relationship to democracy. On the one hand, the social pact is intrinsically and necessarily a democratic act; an act that requires unanimity and a concerted action by which 'many' become 'one'. However, there is an important analytical distinction to have in mind, namely, that between sovereignty and the sovereign. While sovereignty is the result of a radical democratic act - the constitution of itself as such - the sovereign is the instantiation of this supreme power, which can be represented through different forms of government. The government, i.e., the executive force that commands the city is the head of the City; while sovereignty is its soul, which lives through the representation of its power, incarnated in a democratic, aristocratic or monarchical form of government ${ }^{6}$. The advantage of monarchy over the other two forms of government is due to the total coincidence between the artificial and the natural person: the King represents the sovereign power and is himself the sovereign. In a democratic context there are conceptual and practical problems that make more difficult to sustain a well-ordered society.

The first problem is the relationship between 'the people' and the multitude. While the constitution of sovereignty implies the constitution of 'the people' as political subject, this does not mean that the multitude (and its associated dangers) is permanently eradicated. While the strategies for subjectivization aim at keeping every body in its proper place, individual subjects are tempted by possibilities, which arise more intensively in democratic contexts. This is our second problem, namely, that while in all forms of government there is a risk that the ruler enriches his friends or favorites, democracy is more open to the spectacle of demagogues. In a monarchy, the King may offer favors so some officers and friends; but in a democracy, 'where many are to be satisfied, and always new ones, this cannot be done without the Subjects oppression.' (Hobbes, 1984, p.133) Democratic assemblies are not fit for consultation, because they simply create the space for the exhibition of eloquence and persuasion, which appeals to passions and takes the people away from reasoning: 
For this is to perswade; and though they reason, yet take they not their rise from true Principles, but from vulgar received opinions, which, for the most part, are erroneous; neither endeavor they so much to fit their speech to the nature of the things they speak of, as to the Passions of their minds to whom they speak; whence it happens that opinions are delibered not by right reason, but by a certain violence of the mind. Nor is this fault in the Man, but in the nature it selfe of Eloquence, whose end (as all the Masters of Rhetorick teach us) is not truth (except by chance) but victory, and whose property is not to inform, but to allure. (Hobbes, 1984, p.137)

The articulation of these two problems leads to a third reason to be suspicous democracy, namely, that democracy is more propitious to factions, seditions and civil war. Since democracy is incapable of escaping the pressing possibility of the people being transformed into factions and into a disfigured multitude, it is also more propitious for the emergence of its opposite: either tyrannical demagogues or populists. In both cases, the people is generally more oppressed than in other forms of government, and it is easily transformed into a amorphous monster deprived of a political nature.

From what we have seen it is clear that Hobbes is a pertinent author to understand the conditions for civil disobedience today in democratic contexts, even if under specific conditions. Recall that for Hobbes a) the Sovereign has to keep peace, but also conditions for its citizens to have comfortable lives and b) security must be guaranteed at all costs. Let me conclude by giving an example. One could argue that the tensions in Brazilian democracy are what make of it democratic. But how should we approach the reality of economic inequality (and its necessary relation to violence) and (in)security? If insecurity dominates, where would that place subjects and their duties towards the State? Is the civil state dissolved as soon as security and peace are no longer kept? Who decides when the State is no longer the State, where sovereignty is practically dissolved? There are many states in Brazil where security is kept to a minimum, i.e., security exists to prevent a higher escalade of violence, but it cannot control violent deaths. Under this light, there are many Brazilian states where the state of nature seems to be much more real as a description of reality that a civil state. Brazil has criminal rates higher than countries that are in civil war, which forces us to question how well-ordered is Brazilian society. Under this scenario one would be tempted to say that the Brazilian people has the right to disobey. However, and this is Hobbes' radical insight, acts of disobedience are not acts of 'the people' but already of a dissolved people that become, again, a disfigured multitude. If one looks at the dynamics of protesting in Brazil, it seems accurate to say that there is no people in the streets, but only factions, groups of individuals who remain singulars, even if associated, but not united.

In this paper I tried to show how radical is Hobbes' theory of political authority, by offering a new conceptualization of the relationship between obedience, obligation, freedom and servitude. Despite Hobbes' suspicion of democracy, there is a fundamental political act, which is always democratic in nature, namely, the act of constitution of civil state. This act reminds us that there individuals have an inalienable freedom, i.e., even if natural freedom is transfigured once individuals become subjects and are subjectified to become docile and cooperatives, the right of self-preservation remains intact. This right of self-preservation justifies political rupture in Hobbes' design, even if at the expense of destroying the people's unity and rebuilding it again.

\section{BIBLIOGRAPHY}

BYRON M. (2015). Submission and Subjection in Leviathan: Good Subjects in the Hobbesian Commonwealth, London/NY: Palgrave Macmillian. 
FLIKSCHUH K. (2012). Elusive Unity: The General Will in Hobbes and Kant. Hobbes Studies 25: $21-42$

GUYER P. (2012). Hobbes is of the Opposite Opinion. Kant and Hobbes on the Three Authorities in the State. Hobbes Studies 25:91-119.

HOBBES T. (1984). De Cive. New York: Oxford University Press.

HOBBES T. (1998). Leviathan. Oxford: Oxford World's Classics.

HAMILTON L. (2014). Freedom is Power - Liberty through political participation. Cambridge: Cambridge University Press.

JAKONEN M. (2016). Needed but unwanted. Thomas Hobbes's Warnings on the Dangers on the Dangers of Multitude, Populism and Democracy. Las Torres de Lucca 9:.89-118.

SALZBORN S. (2015). No sovereignty without freedom: Machiavelli, Hobbes and the Global Order on the Twenty-first century. Theoria, 144, vol.62 (3): 19-39.

SKINNER Q. (2008). Hobbes and Republican Liberty. Cambridge: Cambridge University Press.

SREEDHAR S. (2010). Hobbes on Resistance - Defying the Leviathan. Cambridge: Cambridge University Press.

VENEZIA L. (2015). Hobbes on Legal Authority and Political Obligation, London/New York: Palgrave Macmillan.

\section{Notas}

1 As Byron points out regarding the dynamics of the state of nature, "normativity is grounded neither in obligation nor in justice, as those concepts are unavailable in the primary state of nature.' (Bryon, 2015, p.24)

2 Regardless of the mode through which the commonwealth comes to existence (by institution or by acquisition), one observes the interdependent relationship between a set of concepts: freedom, submission, obligation, duty, are all concepts that can only be defined in terms of each other. At this point one must ask if there is an analytical distinction between subjection and submission. Byron tells us "The activity of subjection is distinct from the act of submission, which is, at least in theory if not always in practice, once-for-all. Moreover, submission is the last act a person performs in a state of nature, whereas subjection is an ongoing activity in a commonwealth." (Byron, 2015, p. 83)

3 In chapter XXI of Leviathan, Hobbes speaks of the liberty of the subjects. Previously Hobbes said that freedom, properly considered, means only freedom of movement of bodies, not of souls or of wills. Freedom, in the proper sense, it is corporal freedom, i.e., 'freedom from chains and prison' (Hobbes, 1998, p. 130) Because it is a mechanic account of freedom, which ruptures with the Aristotelian tradition that tied us in a ontological dualism, Hobbes is capable of establishing relationships between freedom and passions. Now, he is concerned with the dialectical relationship between obligation and freedom. If the Commonwealth is the artificial person who grants sufficient conditions for peace and conservation, it is also the horizon where freedom is redefined.

4 It should be strengthened again that Hobbes is a materialist; he conceives everything via movement of bodies, of particles; freedom is not a metaphysical property, nor is it an end in itself, as it will be later for Kant. That is why the only two circumstances, which allow for disobedience are those which put into check one's own survival. Because freedom is freedom of movement, freedom of the body, there is no need to enter a meta-level of justification.

5 See Venezia, 2015, p. 92

6 See Hobbes, 1984, p.104. 